\title{
ANALISIS KEMAMPUAN LITERASI SAINS PESRTA DIDIK DITINJAU DARI KEMAMPUAN MENYELESAIKAN SOAL FISIKA DI SMAN 2 BULUKUMBA
}

\author{
1)Andi Pratiwi Irwan, ${ }^{2)}$ Usman, ${ }^{3)}$ Bunga Dara Amin \\ ${ }^{1,2,3)}$ Universitas Negeri Makassar \\ Kampus UNM Parangtambung Jln. Daeng Tata Raya, Makassar, 90224 \\ 1)e-mail: pratiwiirwan@gmail.com
}

\begin{abstract}
Abstrak. Penelitian ini bertujuan untuk: (1)Untuk mengetahui gambaran kemampuan literasi sains peserta didik ditinjau dari kemampuan menyelesaikan soal fisika di SMAN 2 Bulukumba; (2)Untuk mengetahui faktor-faktor yang mempengaruhi kemampuan literasi sains peserta didik ditinjau dari kemampuan menyelesaikan soal fisika di SMAN 2 Bulukumba. Jenis penelitian ini adalah penelitian ex-post facto. Sampel penelitian berjumlah 39 orang yang dipilih melalui random sampling. Hasil penelitian berdasarkan analisis deskriptif dan triangulasi data menunjukkan bahwa peserta didik dapat menjawab soal dengan baik dan benar paling tinggi pada indikator pengetahuan konten indikator mengevaluasi dan merancang penyelidikan ilmiah dikarenakan dalam menjawab soal tersebut peserta didik mengandalkan hafalan mereka terkait materi yang ada pada soal. Sedangkan, kesalahan paling banyak dilakukan peserta didik pada soal dengan indikator pengetahuan epistemik dan indikator menafsirkan data dan bukti secara ilmiah dikarenakan dalam menjawab soal tidak mengendalkan hafalan peserta didik melainkan kemampuan berfikir untuk memahami sebuah hal dan memberikan alasan maupun kesimpulan atas hal tersebut. Serta faktor-faktor yang mempengaruhi kemampuan literasi sains peserta didik ditinjau dari kemampuan menyelesaikan soal fisika diantaranya adalah faktor perilaku guru selama proses pembelajaran yang kurang dalam pemberian bimbingan kepada peserta didik dalam pengerjaan soal, faktor minat peserta didik terhadap fisika yang kurang, faktor kebiasaan belajar peserta didik ketika diberi tugas saja.
\end{abstract}

Kata Kunci: Literasi Sains, Kemampuan menyelesaikan soal fisika

\begin{abstract}
Analysis of Students' Scientific Literacy in Terms of Their Ability to Solve Physics Questions in SMAN 2 Bulukumba. This study aims to: (1) To determine the description of students' scientific literacy skills in terms of their ability to solve physics problems at SMAN 2 Bulukumba; (2) To find out the factors that influence students' scientific literacy skills in terms of their ability to solve physics questions at SMAN 2 Bulukumba. This type of research is ex-post facto research. The research sample amounted to 39 people selected through random sampling. The results of the study based on descriptive analysis and data triangulation showed that students can answer the questions well and correctly the highest on the knowledge indicator the content indicators evaluate and design scientific investigations because in answering these questions students rely on their memorization related to the material in the questions. Whereas, the most mistakes made by students on questions with epistemic knowledge indicators and indicators interpreting data and evidence scientifically because in answering questions do not relax the rote learners but the ability to think to understand a thing and give reasons and conclusions on it. As well as the factors that influence the scientific literacy abilities of students in terms of the ability to solve physics questions, among them are factors of teacher behavior during the learning process that are lacking in providing guidance to students in the execution of questions, lack of student interest in physics, participant learning habits students when given assignments.
\end{abstract}

Keywords: Scientific Literacy, Ability to solve physics questions

\section{PENDAHULUAN}

Pendidikan sains berkontribusi dalam pengembangan kemampuan dalam memahami penggunaan ilmu pengetahuan yang diperoleh secara efektif dalam kehidupan sehari-hari, sehingga pemahaman mengenai sains tidak hanya sebatas teori melainkan juga dari segi implementasinya.

Fisika merupakan salah satu cabang dari ilmu sains yang mempelajari tentang alam dan hal-hal yang berkaitan dengannya serta perubahanperubahan yang terjadi didalamnya. Tujuan pembelajaran fisika adalah membentuk kemampuan bernalar pada diri siswa yang tercermin melalui kemampuan berfikir kritis, logis, sistematis, dan memiliki sifat objektif, jujur, disiplin dalam memecahkan suatu permasalahan baik dalam bidang fisika, bidang ilmu lain, maupun dalam kehidupan sehari-hari (Hastuti, 2012 dalam Putri, Firdaus, \& 
Angraeni, 2018). Berdasarkan pemahaman diatas dapat dikatakan bahwa pendidikan sains khususnya fisika memiliki andil dalam pengembangan literasi sains peserta didik.

Menurut PISA, literasi sains adalah:

"The capacity to use scientific knowledge, to identify questions and to draw evidence-based conclusions in order to understand and help make decisions about the natural world and the changes made to it through human activity." (OECD, 1999)

Hal ini menunjukkan bahwa literasi sains menggunakan pengetahuan ilmiah untuk mengidentifikasi pertanyaan dan untuk menarik kesimpulan yang berdasar bukti dalam hal untuk memahami dan mengeambil keputusan. Selain itu, penilaian untuk literasi sains menurut PISA berdasar kepada 4 aspek dalam yaitu:

a. Aspek konteks sains, yaitu penilaian terhadap kompetensi dan pengetahuan peserta didik dalam konteks/situasi tertentu;

b. Aspek kompetensi, melingkupi kemampuan menjelaskan fenomena secara ilmiah, mengevaluasi dan merancang penyelidikan ilmiah, serta menafsirkan data dan bukti secara ilmiah;

c. Aspek pengetahuan, yaitu penilaian terhadap pemahaman peserta didik mengenai fakta, konsep, dan teori pokok yang membentuk dasar dari pengetahuan ilmiah;

d. Aspek sikap, menunjukkan minat pada sains, dukungan untuk penyelidikan ilmiah, dan motivasi untuk bertindak secara bertanggung jawab terhadap, misalnya, sumber daya alam dan lingkungan (OECD, 2012).

Berdasarkan U.S. Departement of Education, (2015), Indonesia berada pada peringkat 62 dari 70 negara dengan skor 403. Skor yang diperoleh berada di bawah standar Internasional yang telah ditetapkan yaitu sebesar 496. Hal ini menunjukkan bahwa kemampuan literasi sains peserta didik berada pada kategori rendah. Hal ini dikarenakan rata-rata kemampuan sains siswa Indonesia masih pada tahap mengenali fakta dasar, dan mereka belum mampu mengkomunikasikan dan mengaitkan berbagai topik sains. Hal ini mengakibatkan mereka mengalami kesulitan dalam membuat hubungan antara konsep materi pelajaran dengan aplikasi dalam kehidupan sehari-hari dalam menggunakan sains untuk memecahkan berbagai permasalahan yang terjadi (Ahmad, Enawaty, \& Lestari, 2018).

Kemampuan literasi sains peserta didik dapat diamati dari kemampuan mereka dalam menyelesaikan soal fisika yang diberikan. Dengan mengidentifikasi kemampuan literasi sains peserta didik, maka dapat diketahui penanganan yang tepat untuk mengatasi kekurangan yang ada dalam pembelajaran untuk meningkatkan kemampuan literasi sains peserta didik, serta kesalahan dalam menyelesaikan soal dapat berkurang dan tujuan pembelajaran dapat tercapai dengan optimal.

\section{METODE}

Penelitian ini merupakan penelitian ex-post facto. Populasi dalam penelitian ini adalah peserta didik kelas XI MIPA di SMA Negeri 2 Bulukumba. Pengambilan sampel penelitian ini menggunakan teknik random sampling yaitu dengan sistem undian. Jumlah sampel sebanyak 39 orang atau sebesar 30\% dari populasi yang berjumlah 131 orang.

Variabel dalam penelitian ini adalah Kemampuan Literasi Sains Peserta Didik ditinjau dari Kemampuan Menyelesaikan Soal Fisika yang merupakan kemampuan peserta didik untuk menerapkan pengetahuan dan pemahaman sains untuk menyelesaikan sebuah permasalahan dalam bentuk soal yang diberikan berdasarkan aspek pengetahuan dan aspek kompetensi. Indikator pada aspek pengetahuan, yaitu pengetahuan konten, pengetahuan prosedural, dan pengetahuan epistemik. Sedangkan pada aspek kompetensi, yaitu indikator menjelaskan fenomena secara ilmiah, mengevaluasi dan merancang penyelidikan ilmiah, serta menafsirkan data dan bukti secara ilmiah.

Teknik pengumpulan data yang akan digunakan dalam penelitian ini adalah metode tes, metode dokumentasi dan metode wawancara. Instrumen yang digunakan dalam penelitian ini adalah soal-soal fisika 
yang berupa soal uraian atau essay sebanyak 6 butir soal. Soal yang dibuat berbasis literasi sains pada materi gelombang bunyi.

Penelitian menggunakan analisis deskriptif. Teknik analisis ini bermaksud untuk mendeskripsikan atau menggambarkan data yang telah terkumpul. Untuk data yang diperoleh yaitu pada hasil tes serta data hasil dokumentasi akan ditentukan besarnya persentase dari aspek literasi sains dan data hasil tes dilakukan perhitungan ratarata (mean) serta standar deviasi.

Hasil tes perolehan nilai peserta didik selanjutnya akan dikategorikan menjadi tiga yaitu tinggi, sedang, dan rendah yang pengkategoriannya berdasarkan tabel berikut (Arikunto dalam Yana, 2018).

Tabel 1. Kategori Tingkat Kemampuan Literasi Sains Peserta Didik

\begin{tabular}{cc}
\hline Kategori & Keterangan \\
\hline Tinggi & $x>\bar{x}+S$ \\
Sedang & $\bar{x}-S \leq x \leq \bar{x}+S$ \\
Rendah & $x<\bar{x}-S$ \\
\hline
\end{tabular}

Analisis data juga menggunakan analisis model Miles dan Huberman pada lembar jawaban peserta didik serta hasil wawancara. Berdasarkan analisis model Miles dan Huberman (Wijaya, 2018), aktivitas dalam analisis data yaitu, data reduction, data display, dan conclusion drawing/verification.

\section{HASIL DAN DISKUSI}

Pemeriksaan lembar jawaban peserta didik yang dijadikan sebagai sampel penelitian diperoleh skor tes kemampuan literasi sains peserta didik tersebut yang hasilnya dapat dilihat pada tabel berikut.

Tabel 2. Hasil analisis skor tes peserta didik

\begin{tabular}{lc}
\hline \multicolumn{1}{c}{ Statistik } & Skor \\
\hline Skor maksimum soal & 12 \\
Skor minimun soal & 0 \\
Skor tertinggi peserta didik & 9 \\
Skor terendah peserta didik & 2 \\
Skor rata-rata & 5.7 \\
Standar deviasi & 1.4 \\
\hline
\end{tabular}

Perolehan skor rata-rata dan standar deviasi yang diperoleh digunakan untuk mengelompokkan peserta didik berdasarkan tabel 1. Peserta didik dikelompokkan menjadi 3 kategori yaitu tinggi, sedang, dan rendah. Hasil distribusi perolehan nilai literasi sains peserta didik berdsarkan kategori dapat dilihat pada tabel berikut.

Tabel 3. Distribusi Perolehan nilai peserta didik tiap ketegori

\begin{tabular}{ccc}
\hline Kategori & Rentang Skor & Jumlah siswa \\
\hline Tinggi & $\geq 7.1$ & 4 \\
Sedang & $4.4-7.0$ & 28 \\
Rendah & $\leq 4.3$ & 7 \\
\hline
\end{tabular}

Perolehan skor peserta didik pada tes kemampuan literasi sains, kemudian didistribusikan tiap nomor soal untuk masing-masing skor yang diperoleh peserta didik. Berdasarkan pendistribusian skor perolehan tiap nomor soal, maka persentase skor perolehan pada tiap nomor soal berdasarkan indikator aspek literasi sains dapat diamati pada diagram berikut.

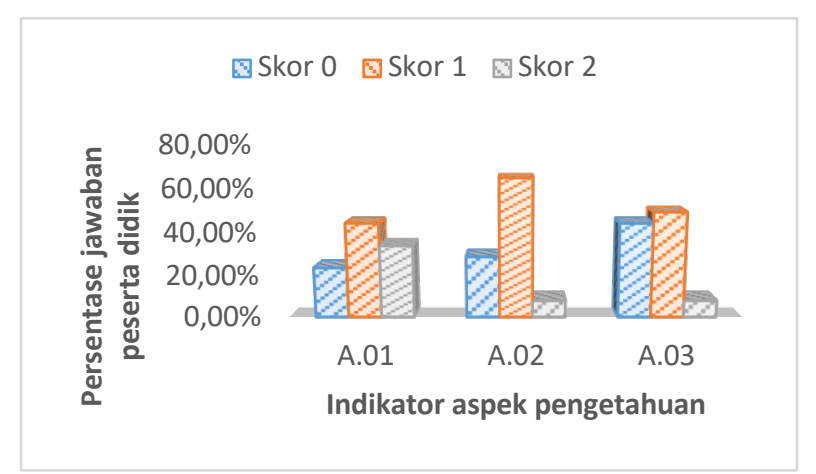

Gambar 1. Diagram persentase jawaban peserta didik berdasarkan indikator aspek pengetahuan

Keterangan:

A.01 = Pengetahuan konten (soal nomor 1 )

A.02 = Pengetahuan prosedural (soal nomor 2 )

A.03 = Pengetahuan epistemik (soal nomor 3 )

Soal nomor 1 dengan indikator pengetahuan konten, peserta didik banyak memperoleh skor 0 karena kurang memahami maksud soal karena mereka memberikan penjelasan yang tidak ada kaitan dengan fenomena yang diberikan ataukah mereka menuliskan secara keseluruhan karakteristik gelombang bunyi meskipun tidak ada kaitan dengan fenomena yang diberikan. Peserta didik yang memperoleh skor 1 , sudah mampu mengidentifikasi 
karakteristik gelombang bunyi terkait fenomena yang diberikan namun tidak menjelaskan karakteristik tersebut sesuai permintaan soal.

Soal nomor 2 dengan indikator pengetahuan prosedural, peserta didik mendapatkan skor 0 karena menuliskan langkah-langkah hanya sebatas penggunaan alat namun tidak menjelaskan pengambilan datanya ataukah menjawab hanya sebatas teknologi yang digunakan pada alat tersebut. Serta pada nomor ini kebanyakan peserta didik mendapat skor 1 dan hanya sedikit yang memperoleh skor 2 karena hanya beberapa peserta didik yang menuliskan cara memperoleh variabel yang dibutuhkan dan rumus yang digunakan sedangkan kebanyakan yang lain antara menuliskan cara memperoleh variabel yang dibutuhkan ataukah menuliskan rumus yang digunakan.

Soal nomor 3 dengan indikator pengetahuan epistemik, peserta didik mendapatkan skor 0 karena menuliskan jawaban dengan tidak mengaitkannya dengan data pada soal yaitu penggunaan gelombang bunyi pada kelelawar namun mangsa tidak kabur. Serta pada nomor ini kebanyakan peserta didik menjawab dengan skor 1 dan hanya sedikit yang memperoleh skor 2 karena hanya beberapa peserta didik yang menuliskan bahwa mangsa tidak kabur karena tidak mendengar suara yang dipancarkan kelelawar serta waktu yang sekilas mengakibatkan mangsa tidak memiliki waktu untuk kabur sedangkan kebanyakan yang lain antara menuliskan karena tidak mendengar ataukah karena tidak memiliki waktu untuk kabur.

Pada aspek pengetahuan, peserta didik yang menjawab soal dengan skor maksimum yaitu 2 paling banyak pada soal dengan indikator pengetahuan konten. Meskipun pada soal dengan indikator pengetahuan konten yang mendapat skor 1 lebih sedikit dibanding pada soal dengan indikator pengetahuan prosedural dan pengetahuan epistemik, namun peserta didik yang menjawab salah atau mendapat skor 0 pada soal dengan indikator pengetahuan konten jauh lebih sedikit dibanding pada soal dengan indikator pengetahuan prosedural dan indikator pengetahuan epistemik.

Sehingga dapat ditarik kesimpulan bahwa pada aspek literasi sains yaitu aspek pengetahuan, peserta didik dapat menjawab soal dengan baik dan benar paling tinggi pada indikator pengetahuan konten kemudian indikator pengetahuan prosedural, terakhir indikator pengetahuan epistemik.

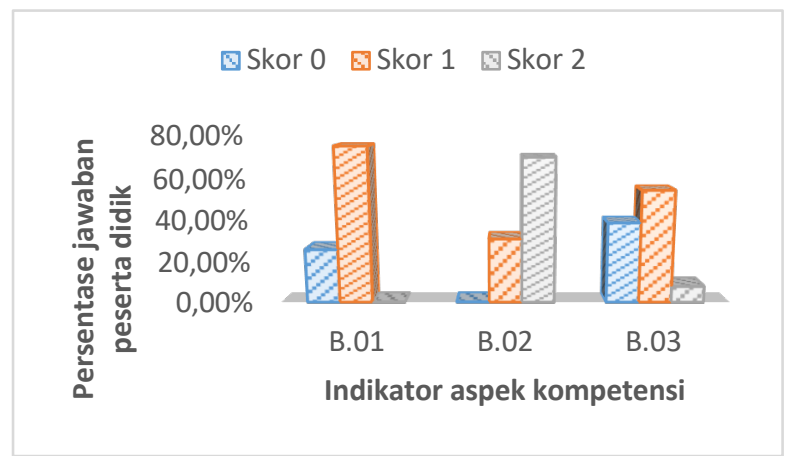

Gambar 2. Diagram persentase jawaban peserta didik berdasarkan indikator aspek kompetensi

Keterangan:

B.01 = Menjelaskan fenomena secara ilmiah (soal nomor 4)

B.02 = Mengevaluasi dan merancang penyelidikan ilmiah (soal nomor 5)

B.03 = Menafsirkan data dan bukti secara ilmiah (soal nomor 6)

Soal nomor 4 dengan indikator menjelaskan fenomena secara ilmiah, peserta didik mendapat skor 0 karena tidak menjelaskan bagaimana fenomena ekolokasi dari kelelawar dapat membantunya terbang di malam hari. Mayoritas peserta didik mendapat skor 1 dan tidak ada yang mendapat skor 2, hal ini karena peserta didik hanya bisa menjelaskan bagaimana ekolokasi dapat membantu kelelawar yaitu dengan bunyi pantulan yang dikeluarkan, namun tidak mengidentifikasi bahwa adanya perbedaan frekuensi sehingga objek yang terkena pancaran suara dapat dibedakan.

Soal nomor 5 dengan indikator mengevaluasi dan merancang penyelidikan ilmiah, tidak ada peserta 
didik yang memperoleh skor 0. Peserta didik memperoleh skor 1 karena tidak menuliskan variabel yang diketahui ataukah salah dalam penggunaan rumus hal ini akibat kurang memperhatikan intruksi pada soal yang diberikan. serta mayoritas memperoleh skor 2 dengan menuliskan variabel yang diketahui serta penggunaan rumus yang tepat serta hasil perhitungan yang benar. Meskipun ada beberapa yang menggunakan rumus yang telah dipelajari sebelumnya dan bukan berdasarkan instruksi yang ada pada teks.

Soal nomor 6 dengan indikator menafsirkan data dan bukti secara ilmiah, peserta didik mendapat skor 0 karena menuliskan jawaban yang tidak berdasarkan data yang ada pada soal. kebanyakan peserta didik hanya mendapat skor 1 dan hanya sedikit yang memperoleh skor 2, hal ini karena hanya beberapa peserta didik yang menuliskan penafsiran data secara terperinci kemudian menarik kesimpulan berdasrkan penafsiran data tersebut. Sedangkan yang memperoleh skor 1 menjawab antara menuliskan penafsiran data secara terperinci ataukah menuliskan kesimpulan dari data tanpa menuliskan penafsiran data terlebih dahulu.

Pada aspek kompetensi, peserta didik yang menjawab soal dengan skor maksimum yaitu 2 paling banyak pada soal dengan indikator mengevaluasi dan merancang penyelidikan ilmiah. Meskipun pada soal dengan indikator mengevaluasi dan merancang penyelidikan ilmiah yang mendapat skor 1 lebih sedikit dibanding pada soal dengan indikator menjelaskan fenomena secara ilmiah dan menafsirkan data dan bukti secara ilmiah, namun peserta didik yang menjawab salah atau mendapat skor 0 pada soal dengan indikator mengevaluasi dan merancang penyelidikan ilmiah jauh lebih sedikit dibanding pada soal dengan indikator menjelaskan fenomena secara ilmiah dan indikator menafsirkan data dan bukti secara ilmiah.

Sehingga dapat ditarik kesimpulan bahwa pada aspek literasi sains yaitu aspek kompetensi, peserta didik dapat menjawab soal dengan baik dan benar paling tinggi pada indikator mengevaluasi dan merancang penyelidikan ilmiah kemudian indikator menjelaskan fenomena secara ilmiah, terakhir indikator menafsirkan data dan bukti secara ilmiah.

Banyaknya peserta didik yang menjawab benar pada soal dengan indikator pengetahuan konten dan indikator mengevaluasi dan merancang penyelidikan ilmiah dikarenakan dalam menjawab soal tersebut peserta didik mengandalkan hafalan mereka terkait materi yang ada pada soal. Sedangkan, kesalahan paling banyak dilakukan peserta didik pada soal dengan indikator pengetahuan epistemik dan indikator menafsirkan data dan bukti secara ilmiah. Hal ini dikarenakan pada soal dengan indikator pengetahuan epistemik dan indikator menafsirkan data dan bukti secara ilmiah tidak mengendalkan hafalan peserta didik melainkan kemampuan berfikir untuk memahami sebuah hal dan memberikan alasan maupun kesimpulan atas hal tersebut.

Hal tersebut diatas bersesuaian dengan yang diungkapkan Rusilowati (2014), bahwa siswa lebih pandai menghafal dibandingkan dengan keterampilan proses sains. Hal ini terkait dengan kecenderungan siswa dalam menguasai pengetahuan menggunakan hafalan bukan kemampuan berpikir. Penyebab lain adalah kebiasaan pembelajaran sains di sekolah yang lebih menekankan pada aspek kognitif bukan mengembangkan keterampilan berpikir siswa.

Dalam proses belajar mengajar disekolah, cara guru mengajar memegang peranan penting dalam upaya meningkatkan hasil belajar siswa. Apabila seorang guru dalam pengajaran berpedoman pada dimensi dimensi mengajar yang baik maka akan menimbulkan persepsi yang baik dari siswa, sehingga pada akhirnya guru dikatakan berhasil mengajar siswanya karena menimbulkan kesan yang baik dari siswa. (Sahidin \& Jamil, 2013).

Berdasarkan hasil wawancara diperoleh hasil bahwa cara mengajar guru dimulai dengan menjelaskan gambaran umum materi yang memuat 
indikator pengetahun konten kemudian dilanjut tahap literasi peserta didik kemudian tanya jawab yang juga memuat indikator pengetahun konten. Setelah itu soal-soal diberikan kepada peserta didik pada bagian uji kompetensi. Proses pembelajaran di kelas yang lebih banyak mengerjakan soal tentunya akan mempengaruhi kemampuan literasi sains seseorang. Perkembangan kemampuan literasi sains peserta didik sangat bergantung pada jenis soal yang diberikan.

Selain cara mengajar guru, buku ajar juga termasuk komponen pendidikan yang sangat penting dalam proses pembelajaran. Tersedianya buku ajar yang berkualitas akan mendukung keberhasilan proses pembelajaran. Buku ajar merupakan sumber belajar dan media yang sangat penting untuk mendukung tercapainya kompetensi yang menjadi tujuan pembelajaran, yang mengacu pada kurikulum (Rusilowati, 2014).

Peneliti melakukan analisis terhadap Buku siswa untuk mengidentifikasi aspek literasi sains yang terdapat dalam buku tersebut pada Bab 10. Gelombang bunyi. Persentase tiap aspek literasi sains pada Buku siswa dapat diamati pada diagram berikut.

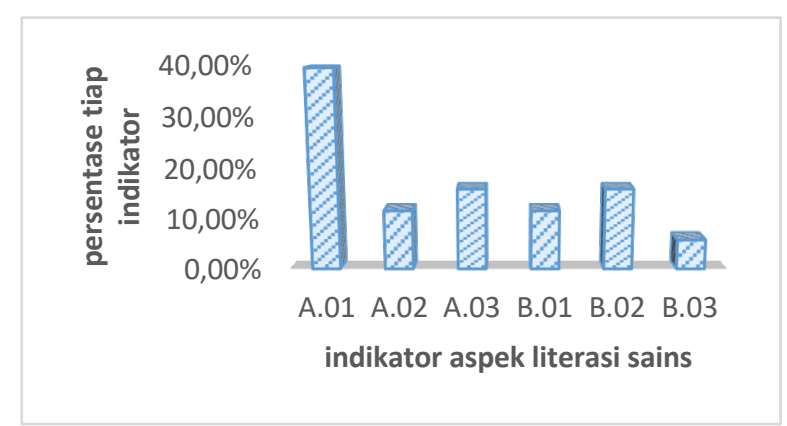

Gambar 3. Diagram persentase aspek literasi sains pada Buku siswa bab 10. Gelombang bunyi

Berdasarkan hasil dokumantasi buku siswa pada Bab 10. Gelombang bunyi tersebut diatas dapat dinyatakan bahwa pada buku siswa tersebut sudah mencakup keseluruhan indikator pada aspek literasi sains. Namun, berdasarkan hasil wawancara yang telah dilakukan peserta didik dalam membaca sebuah buku hanya membaca yang penting yang ingin diketahui dan kebanyakan yang berkaitan dengan tugas yang diberikan sehingga dapat dinyatakan kembali bahwa indikator literasi sains yang dapat dikembangkan dengan membaca buku siswa bergantung pada soal yang diberikan.

Peneliti melakukan pula analisis terhadap Buku siswa untuk mengidentifikasi aspek literasi sains yang terdapat dalam buku tersebut terkhusus pada uji kompetensi pada Bab 10. Gelombang bunyi. Persentase tiap aspek literasi sains pada Buku siswa khusus uji kompetensi dapat diamati pada diagram berikut

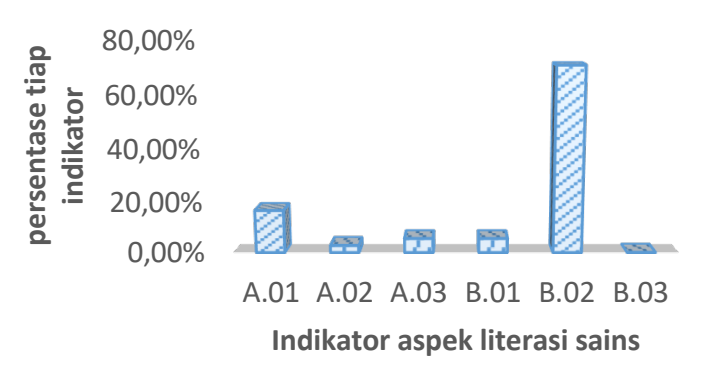

Gambar 4. Diagram persentase aspek literasi sains pada Buku siswa bab 10. Gelombang bunyi Khusus Uji Kompetensi

Berdasarkan hasil dokumantasi buku siswa pada Bab 10. Gelombang bunyi khusus uji kompetensi tersebut diatas dapat dinyatakan bahwa soal uji kompetensi pada buku siswa tersebut hampir mencakup keseluruhan indikator selain indikator menafsirkan data dan bukti secara ilmiah, serta mayoritas soal mencakup indikator mengevaluasi dan merancang penyelidikan ilmiah lanjut pada indikator pengetahuan konten. Sehingga jelas bahwa pemberian soal pada uji kompetensi ini sangat mempengaruhi kemampuan literasi sains peserta didik diamati dari peserta didik yang paling banyak mendapat skor 2 pada soal dengan indikator mengevaluasi dan merancang penyelidikan ilmiah dan pada indikator pengetahuan konten.

Disamping faktor guru sesungguhnya faktor siswa juga tidak kalah penting untuk menjadi pertimbangan dalam proses pembelajaran (Sahidin \& Jamil, 2013). Berdasarkan hasil wawancara yang 
dilakukan untuk mengetahui minat peserta didik terhadap fisika diperoleh bahwa peserta didik yang menyatakan sangat minat dengan fisika berada pada kategori tinggi sedangkan yang menyatakan tidak suka sama sekali dengan fisika berada pada kategori rendah. Responden yang lain yang menyatakan tidak begitu minat dengan fisika ataukah minat yang kadang ada kadang tidak berada pada kategori sedang. Sehingga dapat disimpulkan bahwa minat terhadap fisika dapat mempengaruhi kemampuan literasi sains peserta didik jika ditinjau dari kemampuannya mengerjakan soal fisika.

Pencapaian siswa dalam sesuatu mata pelajaran adalah bergantung kepada minat. Siswa yang memiliki minat terhadap subjek tertentu memberikan perhatian yang lebih besar terhadap subjek tersebut. Minat merupakan faktor yang menentukan tercapainya tujuan belajar. Karena dengan adanya minat untuk belajar dalam diri siswa akan memudahkan guru dalam membimbing dan mengarahkan siswa. Dan siswa yang memiliki kebiasaan belajar cenderung hidup dengan penuh disiplin dan tanggung jawab dalam setiap tindakan belajarnya untuk mencapai prestasi dan hasil belajar yang tinggi (Siagian, 2015).

Berdasarkan hasil wawancara pula dapat diketahui bahwa peran guru dapat mempengaruhi minat belajar fisika dari peserta didik yang menyatakan bahwa kemauan belajar bergantung pada guru yang mengajar. Sebagaimana yang diungkapkan dalam Sahidin \& Jamil (2013) bahwa cara mengajar yang baik akan membuat proses belajar mengajar dapat berlangsung dengan efektif sehingga siswa dapat termotivasi untuk belajar. Motivasi berprestasi yang baik berpengaruh positif pada hasil belajar siswa. Sebaliknya jika motivasi tersebut kurang baik maka akan berpengaruh negatif pada hasil belajar siswa, akibatnya hasil belajarnya akan relatif rendah.

Kebiasaan belajar yang tertanam pada diri siswa dapat terlihat pada aktivitas belajar siswa dan dapat dilakukan secara kontinyu sepanjang waktu yang diinginkan. Kebiasaan belajar mempengaruhi prestasi belajar, karena prestasi belajar yang diperoleh siswa banyak faktor yang mempengaruhinya salah satunya adalah kebiasaan belajar siswa (Siagian, 2015).

Peserta didik sangat jarang memilki waktu luang khusus untuk belajar di rumah sehingga pembelajaran di sekolah harus benar-benar di buat efektif sehingga kemampuan literasi sains peserta didik dapat dikembangkan. Pembelajaran di SMAN 2 bulukumba kelas XI MIPA yang menitik beratkan pada kegiatan mengerjakan soal-soal secara mandiri, maka pemilihan soal harus benar-benar dipertimbangkan dengan baik, memilih soal yang tidak hanya mencakup satu indikator literasi sains saja namun harus menyeimbangkan kadar tiap indikator literasi sains pada setiap soal.

\section{SIMPULAN}

a. Peserta didik dapat menjawab soal dengan baik dan benar paling tinggi pada indikator pengetahuan konten indikator mengevaluasi dan merancang penyelidikan ilmiah dikarenakan dalam menjawab soal tersebut peserta didik mengandalkan hafalan mereka terkait materi yang ada pada soal. Sedangkan, kesalahan paling banyak dilakukan peserta didik pada soal dengan indikator pengetahuan epistemik dan indikator menafsirkan data dan bukti secara ilmiah dikarenakan dalam menjawab soal tidak mengendalkan hafalan peserta didik melainkan kemampuan berfikir untuk memahami sebuah hal dan memberikan alasan maupun kesimpulan atas hal tersebut.

b. Faktor-faktor yang mempengaruhi kemampuan literasi sains peserta didik ditinjau dari kemampuan menyelesaikan soal fisika diantaranya adalah faktor perilaku guru selama proses pembelajaran yang kurang dalam pemberian bimbingan kepada peserta didik dalam pengerjaan soal, pemberian soal kepada peserta didik yang kebanyakan hanya pada satu indikator aspek literasi sains, faktor minat peserta didik 
terhadap fisika yang kurang, faktor kebiasaan belajar peserta didik ketika diberi tugas saja.

\section{SARAN}

a. Pembelajaran yang menitik beratkan pada pengerjaan soal, maka guru harus benar-benar mempertimbangkan dengan baik soal yang akan diberikan kepada peserta didik, memilih soal

\section{DAFTAR RUJUKAN}

Ahmad, Enawaty, E., \& Lestari, I. (2018). Deskripsi Kemampuan Literasi Sains Siswa Kelas XII IPA 1 di SMA Mujahidin Pontianak pada Materi Larutan Asam Basa. Jurnal pendidikan dan Pembelajaran, 7(5). Retrieved Maret 5, 2019, from http://jurnal.untan.ac.id/index.php/jpdpb/arti cle/view/25555

Badan Pengembangan dan Pembinaan Bahasa. (2016). KBBI Daring. Retrieved Juni 25, 2019, from https://kbbi.kemdikbud.go.id/entri/literasi $\% 2$ 0sains

Hill, R. (1998). What Sample Size is "Enough" in Internet Survey Research. IPCT Journal, 6(34).

OECD. (1999). Measuring Student Knowledge And Skill: A New Framework For Assessment. Paris: OECD Publishing.

OECD. (2012). PISA 2012 Assessment and Analytical Framework: Mathematics, Reading, Science, Problem Solving and Financial Literacy. Paris: OECD Publishing.

Putri, S. E., Firdaus, M., \& Angraeni, L. (2018). Analisis Kesalahan Siswa Dalam Menyelesaikan Soal Pada Materi Tekanan Di Kelas VII MTs. Al-Husna Kota Pontianak. Jurnal pendidikan sains dan aplikasinya, l(1), 39-46. yang tidak hanya mencakup satu indikator literasi sains saja namun harus menyeimbangkan kadar tiap indikator literasi sains pada setiap soal.

b. Untuk penelitian selanjutnya, sebaiknya melakukan penelitian untuk mengetahui cara untuk meningkatkan literasi sains peserta didik.

Rusilowati, A. (2014). Analisis Buku Ajar IPA yang Digunakan di Semarang Berdasarkan Muatan Literasi Sains. Proceeding Seminar Nasional Konservasi dan Kualitas Pendidikan 2014, (pp. 6-10). Semarang.

Sahidin, L., \& Jamil, D. (2013). Pengaruh Motivasi Berprestasi dan Persepsi Siswa Tentang Cara Guru Mengajar Terhadap Hasil Belajar Matematika. Jurnal Pendidikan Matematika, 4(2), 211-222.

Siagian, R. F. (2015). Pengaruh Minat dan Kebiasaan Belajar Siswa Terhadap Prestasi Belajar Matematika. Jurnal Formatif, 2(2), 122-131.

U.S. Departement of Education. (2015). Retrieved from PISA 2015 Result: https://nces.ed.gov/surveys/pisa/pisa2015/ind ex.asp

Wijaya, H. (2018). Analisis Data Kualitatif: Ilmu Pendidikan Teologi. Makassar: Sekolah Tinggi Theologia Jaffray.

Wikipedia contributors. (2015). Literasi Saintifik. Retrieved Juni 25, 2019, from https://id.wikipedia.org/wiki/Literasi_saintifi $\mathrm{k}$

Yana, E. T. (2018). Analisis Kemampuan Literasi Sains pada Aspek Kompetensi dan Pengetahuan Calon Guru Fisika pada Materi Gelombang Bunyi. Skripsi. Tidak Diterbitkan. Fakultas Tarbiyah dan Keguruan. Universitas Islam Negeri Raden Intan: Lampung. 